\title{
Taxonomic papers as published products of the biodiversity inventory: if not the Impact Factor (IF) or Quartiles (Q), then what determines their importance estimated on the basis of the Research Interest Score?
}

\author{
Viktorija Dobrynina ${ }^{1^{*}}$, \\ Svetlana Baryshnikova ${ }^{2}$, \\ Eduardas Budrys ${ }^{1}$, \\ Jolanta Rimšaitè \\ Oleksiy Bidzilya ${ }^{3}$ \\ ${ }^{1}$ Institute of Ecology, \\ Nature Research Centre, \\ Akademijos St. 2, \\ Vilnius 08412, Lithuania \\ ${ }^{2}$ Zoological Institute, \\ Russian Academy of Sciences, \\ Universitetskaya nab. 1 , \\ St. Petersburg 199034, Russia \\ ${ }^{3}$ Institute of Evolutionary Ecology, \\ the National Academy \\ of Sciences of Ukraine, \\ Kyiv 03143, Ukraine
}

This study is uniquely based on the Research Interest Score (RGRI) and not on other existing bibliometric criteria for evaluation of published biological inventory products (articles and monographs). RGRI is a ResearchGate.net score that measures scientists' interest in the publication and is based on its citations, recommendations, and reads. Our data revealed that high RGRI scores of publications were generally not determined by the journal's Impact Factor (IF) or high quartiles (Q). However, open access to publications undoubtedly creates the strongest preconditions for the rise of RGRI. The importance and popularity of a publications can also be affected by its various other characteristics, for example, international collaboration of authors, ecological issues such as plant-insect interactions, and even the wording of the publication title.

Keywords: journal ranking, diagnostics, international collaboration, leaf-mining insects, new taxa, open access, plant-insect interactions, title

* Corresponding author. Email: viktorija.dobrynina@gmail.com 


\section{INTRODUCTION}

The term 'biodiversity inventory' is interpreted as studies that cover the diversity of all organisms, including their genetic diversity, interspecific and intraspecific diversity, identification of relationships between species and ecosystems, the diversity of terrestrial and aquatic ecosystems and their evolutionary and ecological processes (Vermeulen, Koziell, 2002; Morton, Hill, 2014). In fact, it is within the field of biological systematics or taxonomy with the ultimate task to document and understand the extent and significance of biological diversity (Vane-Wright, 1992, 1996). Such studies are also needed in order to obtain detailed information on grouping of endangered species (Mckinney, 2002) and, more importantly, to identify and protect critical habitats. The availability and quality of such information is essential for understanding the mechanisms of functioning of the global biota (Pereira et al., 2010), including the development of methods for using incomplete data (Girardello et al., 2019). In order to manage this process of research, technologies for studying various aspects of biodiversity are being developed (e.g., Grummo et al., 2019) and manuals are compiled (Cutko, 2009). Biodiversity inventory or biodiversity assessment has been particularly relevant because of human activities, reckless use of natural resources, destruction and fragmentation of habitats, industrial pollution, and climate change. Biodiversity has undergone dramatic change (Puplesis, 2002; Bellard et al., 2012; Morton, Hill, 2014) and is declining rapidly (Hallmann, 2017; Leather, 2018; SánchezBayo, Wyckhuys, 2019; Zattara, Aizen, 2021).

Another problem is that the inventory of species diversity is often limited to the best-known groups of organisms such as vascular plants and larger vertebrates, and too little attention is being paid to the remaining $80-90 \%$ of taxa (Puplesis, 2002; Hawksworth, 2011).

It is also true as regards the research object of the authors: the formerly largely neglected smallest lepidopterans (Lopes-Vaamonde et al., 2019) and the leaf-mining moths (Gelechiidae, Gracillariidae, Bucculatricidae, Tischeriidae,
Opostegidae, Nepticulidae, etc.). However, taxonomic inventories of these tiny insects can not only provide knowledge about global biota but are also essential for providing tools for prompt measures in the preservation of biodiversity and, along with the data on other organisms, they can provide support for hypotheses about the earlier genesis of the Earth's biota (Stonis et al., 2020b). They have also been used as an express tool for monitoring biodiversity, rapid assessment of biodiversity areas of critical value, and determining priority areas from the environmental point of view in tropical America (Stonis, pers. comm.). On the other hand, larvae of leaf miners are pests or potential pests of wild and cultivated plants; they mine inside green tissues and produce leaf mines (Pitkin et al., 2019; Kirichenko et al., 2019). Although adults of leaf miners are often among the smallest lepidopterans in the world (Stonis et al., 2021b), a leaf mine produced by a tiny larva can be relatively large and cause damage because the larva consumes much of the photosynthetic tissues (Stonis et al., 2021b). Upon significant population increase or explosion, damage to the host plant may be significant or even severe (Puplesis, 1994; Puplesis, Diškus, 2003; Stonis et al., 2021b).

Final products of the biodiversity inventory can vary between online databases (De Prins, De Prins, 2006-2020; Robinson, 2019; Froese, 2019; De Prins, Heughebaert, 2019; Stephenson, Stengel, 2020; Kitching, 2021) and issued publications: taxonomic lists of regional fauna or flora, identification keys, large-scale taxonomic revisions, or global or regional catalogues, etc. For example, the Catalogue of Lepidoptera of Russia (Sinev, 2008) reveals species composition of this huge country, outlines geographical distribution of individual species, and determines territories least studied in terms of the lepidopteran fauna. An important function of this catalogue is the introduction into the practice of domestic research of modern ideas about taxonomy and applying current nomenclature. The catalogue also serves as a very powerful impetus for further taxonomic and especially faunistic research. Therefore, a huge amount of new information accumulated over 
the last decade within this field of the biological inventory resulted in the second revised and supplemented edition of the Catalogue of Lepidoptera of Russia (Sinev, 2019).

Efforts to inventory and monitor global biodiversity appear to be growing (Zhang, 2008, 2011; Cutko, 2009; La Salle et al., 2009; Pereira et al., 2010). The task, however, is huge and the speed is far from sufficient (Schmeller et al., 2017). Among various causes, there is a lack of qualified professionals (Stonis, 2014).

In order to speed up the global inventory, integration of DNA barcoding into an ongoing inventory has been actively propagated (Janzen et al., 2009; Miller, 2015; Miller et al., 2016; Aagaard et al., 2017) and some seriously controversial attempts have recently been undertaken. It is particularly the case of a minimalist revision with description of 403 new species in 11 subfamilies of Costa Rican braconid parasitoid wasps (Sharkey et al., 2021) rejecting the usual standards for species description.

Another alarming situation is that the present funding of research in some countries may depend on the number of publications in the journals that are highly rated (quartiles Q1 and Q2 of a list ranked by the impact factor in a particular category, e.g., entomology) in the Clarivate Analytics Web of Science Core Collection database (hereinafter, IF publications). It indirectly influences biodiversity researchers who are obliged to refer to publications in these high-ranked journals instead of publishing their research in journals dedicated to the biodiversity inventory and aspire to their main goal: to accelerate the process of inventorying the global biodiversity. In some cases, the number of IF publications is considered the only criterion for assessing researchers' performance during the most recent period or electing them for a new term. Meanwhile, papers published in unranked journals (including monographs, articles, or catalogues) or, even more so, the building of faunistic collections are generally not considered and left overboard. Often, this approach not only has a direct negative impact on researchers, but also does not help to maintain biological inventories. This situation is particularly detrimental to young researchers and is increasingly leading to the situation when biodiversity research (especially faunistics) is to a large extent done by amateur entomologists.

The purpose of this study is to analyse the significance and popularity of taxonomic publications as published products of the biodiversity inventory. Various analyses of article citation rates can be found in a number of publications (Falagas et al., 2008; Barreto et al., 2013; Aksnes et al., 2019). However, the change in the significance of scientific articles over time has been very little analysed (Chawla, 2018).

Our study is focused exclusively on the ResearchGate (researchgate.net) Research Interest (RGRI) score and not on other existing bibliometric criteria for the evaluation of published products of the biological inventory (articles and monographs). We are not aware of any cases where the indicators of scientific social networks (namely RGRI) are compared with usual bibliometric indicators.

Research Interest is a ResearchGate.net score that measures scientists' interest in a publication and is based on its citations, recommendations, and reads. It should be mentioned that ResearchGate.net is not simply a 'social club' for researchers registered at this portal: all publications or their abstracts are available to any user via internet search engines. Therefore, the readability of publications from the ResearchGate and their citation appear to be important indicators of whether the published paper has attracted interest or not.

\section{MATERIALS AND METHODS}

A statistical sample and criteria for the selection of a subset. The analysis encompassed 69 publications. The following criteria were applied for the selection of publications: (1) diversity regarding occurrence in journals with different quartile (Q) and impact factor (IF) as well as in non-IF journals; (2) the same subject as regards organism groups and the nature of research; (3) the same recent period of publishing; (4) the presence of an RGRI score enabling comparison of publications, i.e., availability 
of publications on ResearchGate.net. However, publications that conform entirely to all the above-mentioned criteria and comprise corpora large enough for analysis were not numerous. For this reason, we selected publications inventorying plant-mining Microlepidoptera (Insecta: Lepidoptera). The analysis did not compare papers addressing different subject areas, e.g., taxonomic publications were not compared with those dealing with applied research on them as pests. All publications dealing with a certain subject were taken from the database of ReseachGate, mostly (but not exclusively) from the period of 2013-2020 without excluding those which were 'inapplicable' for some reason. Part of the analysed publications dealt with taxonomic diversity of Opostegidae (Davis, Stonis, 2007; Remeikis et al., 2009; Stonis et al., 2013e, 2020f). Others focused on the inventorying of Tischeriidae (Stonis, Diškus, 2007, 2008; Lees, Stonis, 2007; Stonis et al., 2008, 2014a, 2017a, 2018a, 2019a, 2019b, 2019d, 2020a, 2020b, 2020d; Diškus, Stonis, 2015; Xu et al., 2017, 2018; Klasiński et al., 2020; Stonis, Solis, 2020). The subject of some publications was related to various taxonomic groups (Navickaite et al., 2011; Stonis et al., 2015c, 2016a, 2016g, 2019f). The majority of publications selected for analysis dealt exclusively with research on Nepticulidae in Europe and Asia (Stonis, Remeikis, 2011; Rociene, Stonis, 2013, 2014; Stonis, Rocienè, 2013, 2014, Stonis et al., 2015b, 2020e; Navickaite et al., 2014a, 2014b), Central America (Šimkevičiūtè et al., 2009; Stonis et al., 2013a, 2013b, 2013c, 2013d, 2019g; Stonis, Remeikis, 2015), and South America (Remeikis et al., 2014, 2016; Remeikis, Stonis, 2015; Stonis et al., 2014b, 2015a, 2016b, 2016c, 2016d, 2016e, 2016f, 2017b, 2017c, 2017d, 2017e, 2017f, 2018b, 2018c, 2018d, 2018e, 2019c, 2019e, 2019g, 2020c; Stonis, Remeikis, 2016, 2017, 2018; Stonis, Diškus, 2018).

Criteria for the evaluation of the significance and relevance of publications. Although the importance of publications can be estimated by considering data on their reads and citation taken from Google Scholar or Clarivate Analytics, in this analysis, the main criteria for the evaluation of the significance and relevance of pub- lications was a Research Gate Research Interest (RGRI) score. RGRI is a ResearchGate.net score that measures scientists' interest in a publication and is based on its citations, recommendations, and reads. We cannot state that any scores necessarily depend on the quality of a publication. For example, the score for reads alone, as distinct from that for citation, is not always related to the publication quality but almost certainly to the particular title that the reader sees before reading the publication. The selection, therefore, focused on the total score of Research Interest and not on its component parts ('Citations', 'Recommendations', 'Reads', or 'Full-text reads') in order to comprise various aspects of the usage and popularity of a publication. RGRI can be affected by the number of followers of the publication's authors and the number of those being followed within academic social networks. We, therefore, avoided including a wide variety of authors when selecting publications for analysis in order to eliminate, at least in part, the impact of this feature on RGRI.

RGRI is increasing (it is an accumulative score), though it generally stabilizes over time. Therefore, when analyzing the dynamics of RGRI's increase (variation over several years), we selected only those publications which appeared from 2017 to 2020. All the RGRI data for the analysed publications were registered at the same time (16 January 2021), because these data may change in the future.

Analysis. Total values of RGRI scores were balanced with various characteristics of publications: IF, quartiles (Q2, Q3, Q4), Open Access (OA) or its absence, as well as other characteristics of publications which could affect the score value. Statistical assessments were done using Statsoft Statistics, version 8 . The normality of distribution in variables was assessed using the Shapiro-Wilk test. In the cases of normal distribution, we applied the analysis of variance (ANOVA) and the Tukey's 'Honest significant difference' (HSD) test. In other cases, the significance of difference among groups was assessed using the Kruskal-Wallis test and the MannWhitney test. The histograms (Figs. 5-8) were drawn according to the recommendations 
developed by Vilmantas Gègžna (https://mokymai.github.io/biostatistika/).

\section{RESULTS AND DISCUSSION}

\section{Analysis of published biodiversity inventory products (articles and monographs) and their RGRI value}

The analysed publications had very different RGRI values (scores) (Table 1), among which the lowest RGRI value was 0.1 points and the highest 17.2 points. Therefore, all publications were divided into two groups: (1) publications with low RGRI scores, i.e., from 0.1 to 9.9 points $($ mean $=5.1)$ and $(2)$ publications with high RGRI scores, i.e., ten or more points (mean $=12.2$ ). Judging by the value of RGRI alone, the latter group brought together publications that were more relevant and apparently more significant to RG users. It could be expected that the group of higher RGRI values would be dominated by IF publications, while the lower value group by publications published in unrated journals. However, our data showed that both in the group with lower RGRI scores (Fig. 1) and in that with higher RGRI scores (Fig. 2), publications that appeared in IF journals accounted for the largest share.

Table 1. RGRI score of selected publications published in impact factor (IF) and non-IF journals

\begin{tabular}{ccccc}
\hline $\begin{array}{c}\text { Short title of publication } \\
\begin{array}{c}\text { Lamiaceae-feeding Nepticulidae from South } \\
\text { America }\end{array}\end{array}$ & Reference & IF & RGRI value \\
\hline $\begin{array}{cccc}\text { Discovery of the Stigmella magnispinella group } \\
\text { Diagnostics of the Andean Stigmella sinuosa comp lex }\end{array}$ & Stonis et al. 2016f & IF & IF & 4.2 \\
\hline Updated checklist of Nepticulidae of the Crimea & Navickaite et al. 2014b & IF & 2.6 \\
\hline Additions to the Nepticulidae of East Asia & Stonis \& Rociene 2014 & IF & 3.1 \\
\hline New generic concept: Brachinepticula gen. nov. & Stonis et al. 2018c & - & $\mathbf{1 2 . 2}$ \\
\hline Mystery of Urticaceae-feeding Nepticulidae & Stonis et al. 2017a & - & $\mathbf{1 6 . 6}$ \\
\hline A situation requiring urgent action: Colombia & Stonis et al.2015c & - & $\mathbf{1 1 . 0}$ \\
\hline
\end{tabular}

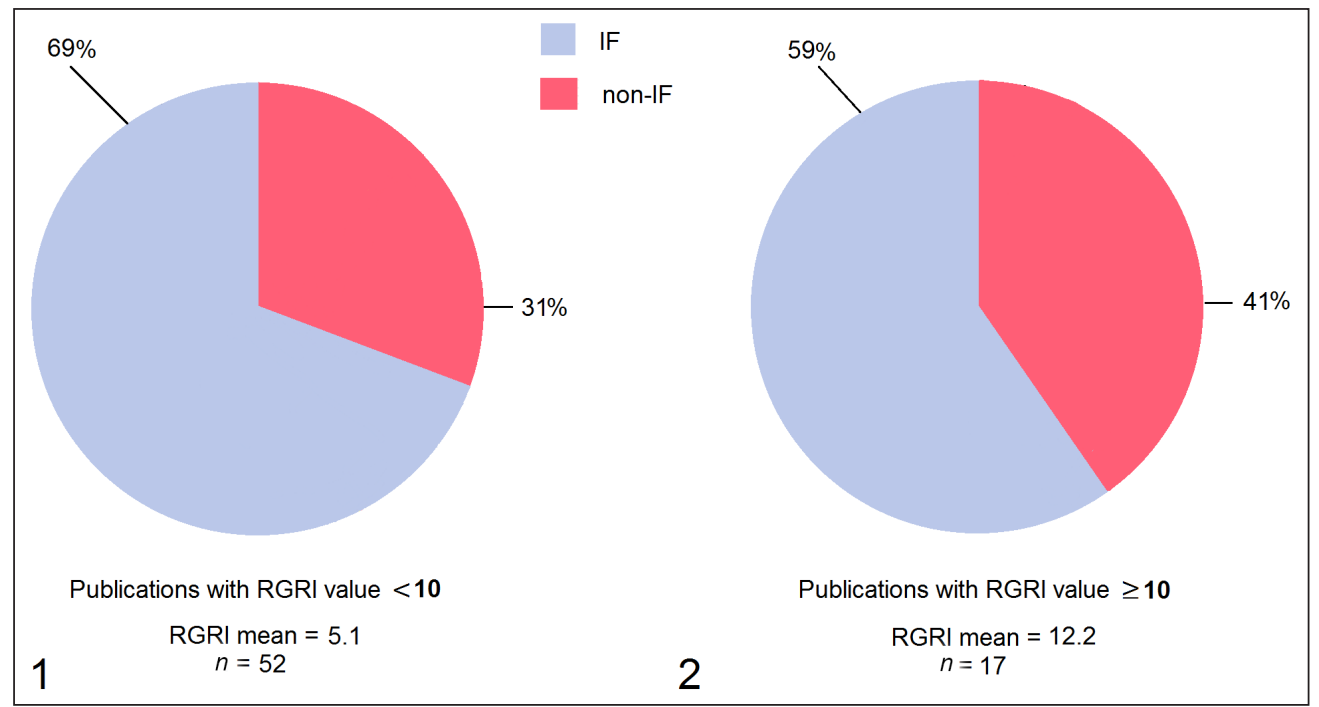

Figs. 1, 2. RGRI value and the share of analysed publications published in IF and non-IF journals. 1 - publications with RGRI values lower than 10 points; 2 - publications with RGRI values of 10 points or more 
Moreover, there were relatively fewer (59\%) IF publications in the group of high RGRI values (Fig. 2). This led us to the conclusion that high RGRI scores (and user interest) were not necessarily earned by publications in IF journals and that the mere fact of being published in IF journals did not guarantee greater readability or citation.

However, when analysing the same groups of publications, we found an obvious correlation of the RGRI value with the availability of open access (OA). Almost exclusively, the group of publications more valuable from the RGRI point of view (with the RGRI value $>10$, mean $=12.2)($ Fig. 4$)$ included open access publications; they made up about $96 \%$ within this group. Meanwhile, among the publications with low RGRI values (Fig. 3), nearly half of all of the publications (45\%) were not open access (Table 2). The increase in RGRI value in relation to OA was confirmed by the data of our analysis (Fig. 5) (T-test: non-OA mean 4.772; OA mean 8.027; t-value 3.711; df 67; $p=0.00042$; non-OA $n=25 ; n=44)$.

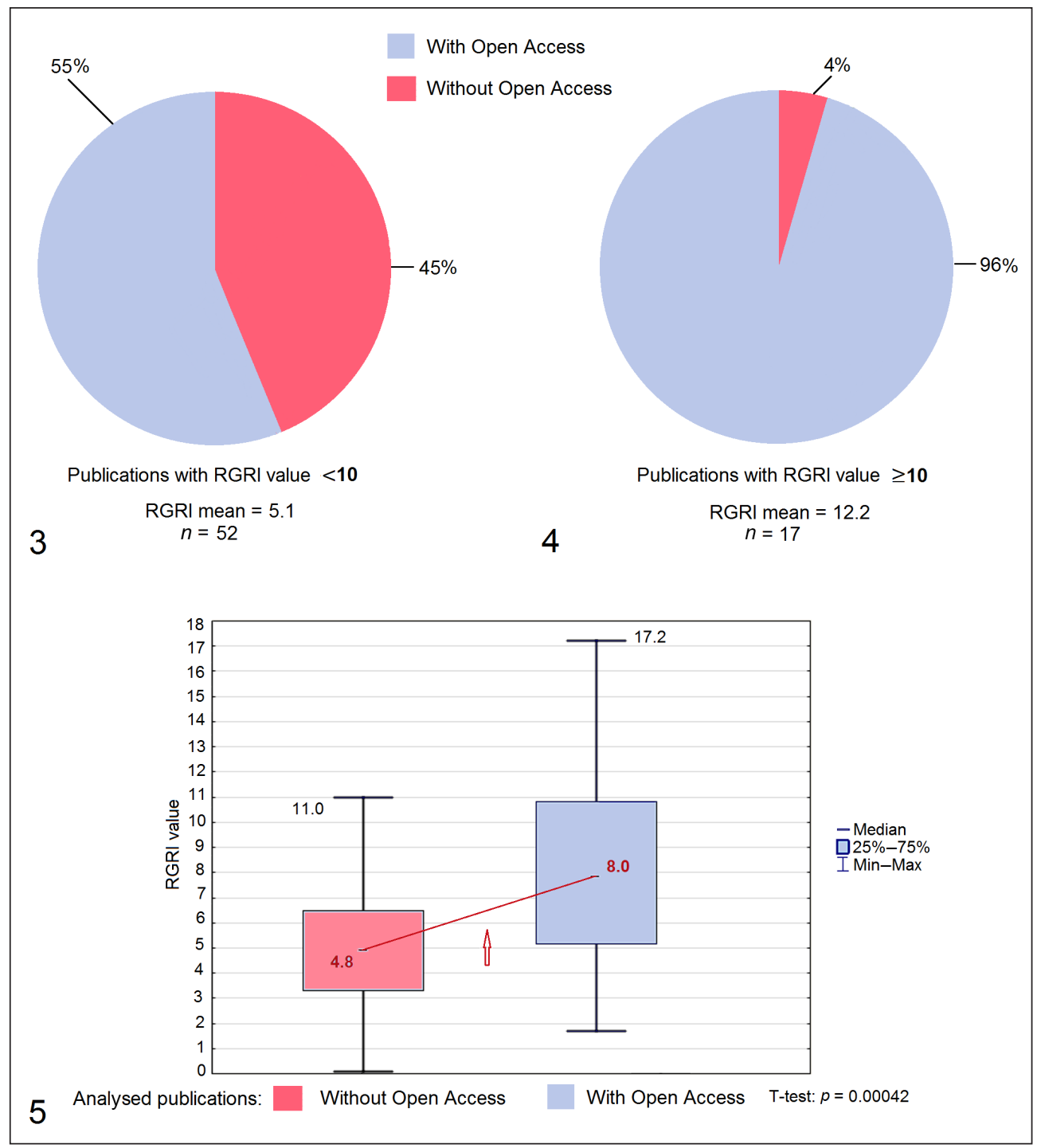

Figs. 3-5. RGRI value and the share of analyzed publications published in journals with open access or without it. 3 - publications with RGRI value less than 10 scores; 4 - publications with RGRI value 10 scores or more; 5 - difference in RGRI median between publications published in journals with open access $(\mathrm{OA})$ and without $\mathrm{OA}$ 
Table 2. RGRI score of selected publications published in open access (OA) and non-OA journals

\begin{tabular}{ccccc}
\hline Short title of publication & Reference & OA & RGRI value \\
\hline Asteraceae feeding Nepticulidae of South America & Stonis et al. 2018b & OA & $\mathbf{1 4 . 7}$ \\
\hline A Gondwanan concept of Simplimorpha & Stonis et al. 2018d & OA & $\mathbf{8 . 5}$ \\
\hline Documentation of guava pest, Enteucha guajavae & Remeikis et al. 2014 & OA & $\mathbf{1 7 . 2}$ \\
\hline $\begin{array}{c}\text { Stigmella purpurimaculae group from the Patagonian } \\
\text { Andes }\end{array}$ & Stonis et al. 2014b & OA & $\mathbf{1 2 . 4}$ \\
\hline $\begin{array}{c}\text { Catalogue of species described by members of BRG } \\
\text { Tischeriidae from South Africa }\end{array}$ & Navickaite et al. 2011 & OA & $\mathbf{1 1 . 9}$ \\
\hline Odd Nepticulidae species from the Andes and Amazon et al. 2019a & - & 0.8 \\
\hline $\begin{array}{c}\text { Discovery of Quercus-feeding Nepticulidae in South } \\
\text { America }\end{array}$ & Remeikis \& Stonis 2015 & - & 3.6 \\
\hline Nepticulidae of the Crimea, Sub-Mediterranean Europe & Navickaite et al. 2014b & - & 2.2 \\
\hline Nepticulidae of East Asia & Rociene \& Stonis 2013 & - & 0.1 \\
\hline
\end{tabular}

When grouping the analysed publications by their quartiles (Q) (Figs. 6, 7), it turned out that quartiles might be of little significance for the RGRI value of publications (Table 3) because in the sample analysed, the highest RGRI values are from the lowest quartile group (Fig. 7) and not vice versa (Fig. 6). However, since there was not a single Q1 item within the group of high quartile items analysed (Fig. 6) and the sample size of this group $(n=16)$ was too small, we could not draw definitive conclusions.
In this study, we hypothesised that international collaboration of the authors might have affected the popularity of published biodiversity inventory products (i.e., the extent of the RGRI value). Although most of the analysed publications were related to international cooperation in one way or another, we included only publications that had been prepared and published as a result of exceptional and highly significant international cooperation into the group 'with international cooperation'.

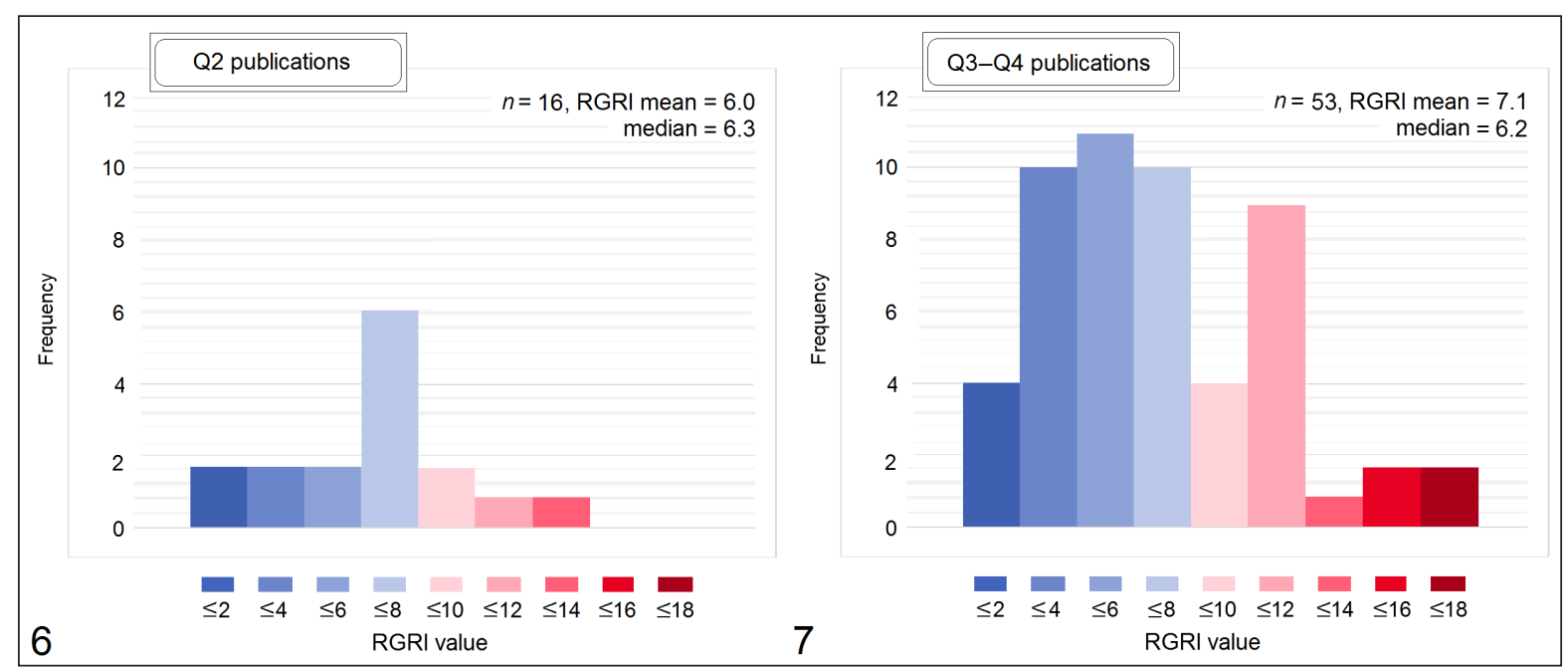

Figs. 6, 7. Frequency of publications with different RGRI values. 6 - publications in Q2 journals; 7 - publications in Q3-Q4 journals 
Table 3. RGRI score of selected publications published in Q2 and Q4 journals

\begin{tabular}{|c|c|c|c|}
\hline Short title of publication & Reference & Q & RGRI value \\
\hline $\begin{array}{l}\text { Exceptional Tischeriidae diversity in Belize, Central } \\
\text { America }\end{array}$ & Stonis et al. 2020a & 2 & 2.5 \\
\hline Nepticulidae of East Asia & Rociene \& Stonis 2013 & 2 & 0.1 \\
\hline Oposteoidae of the Himalaya & Stonis et al. $2013 \mathrm{e}$ & 2 & 0.7 \\
\hline Broadest distribution range: Astrotischeria neotropicana & Diskus \& Stonis 2015 & 2 & 4.9 \\
\hline Urticaceae-feeding Tischeriidae: Paratischeria gen . nov. & Stonis et al. $2017 \mathrm{a}$ & 4 & 14.7 \\
\hline Do Nepticulidae occur in the Polylepis forests? & Stonis et al. $2016 \mathrm{e}$ & 4 & 10.9 \\
\hline A revision of the New World Opostegidae & Davis \& Stonis 2007 & 4 & 11.1 \\
\hline
\end{tabular}

The analysis data also showed that the mean and median RGRI values of publications resulting from international collaboration (IC) were almost twice as high (Fig. 9) than non-IC publications (Fig. 8). In addition, IC publications were significantly more likely to have a higher

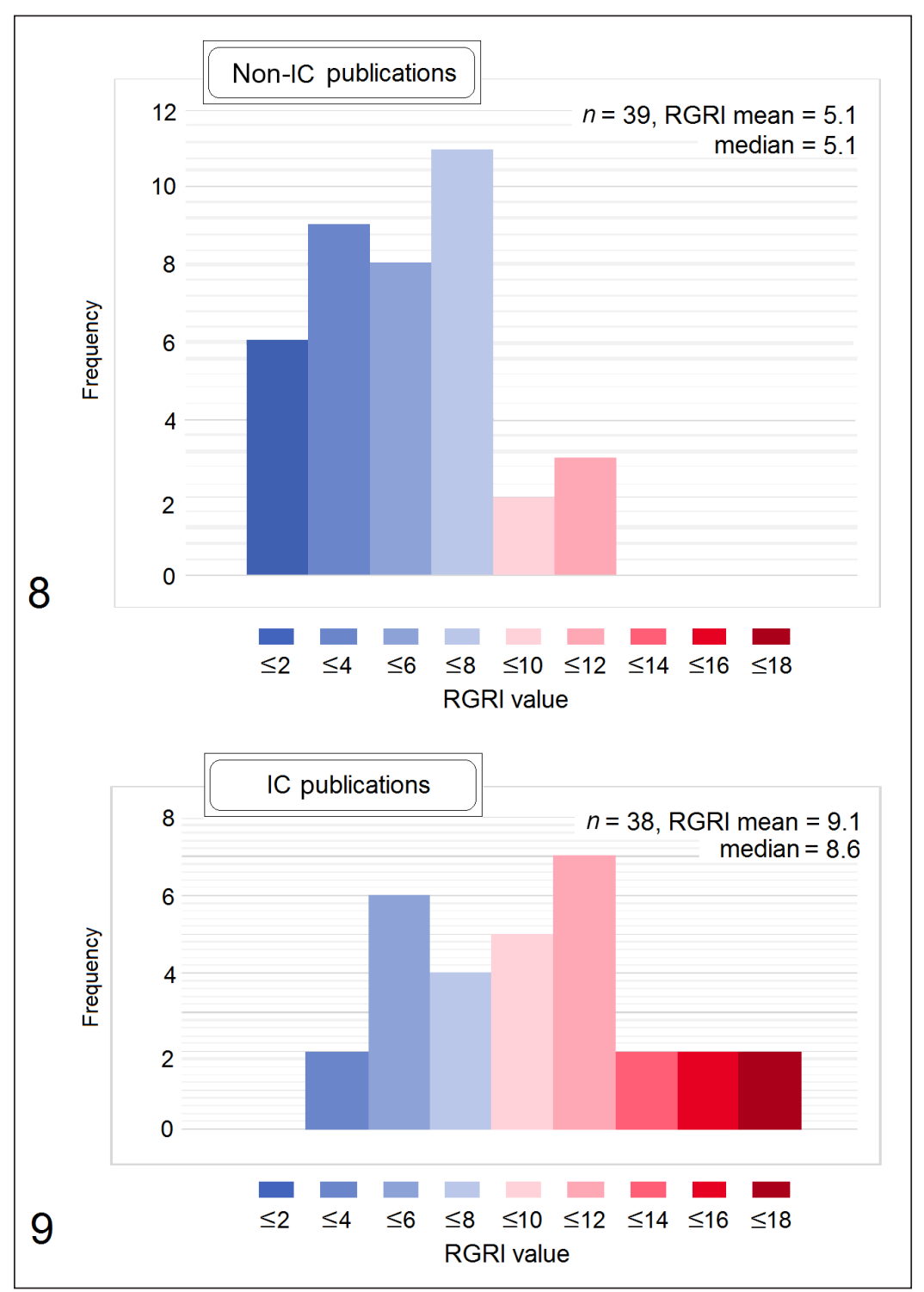

Figs. 8, 9. Frequency of publications with different RGRI values. 8 - publications without distinctive international collaboration (IC); 9 - publications characterized by exceptional IC 
RGRI value than those without IC. It should also be noted that the lower value of RGRI for publications without IC was very low (0.1), and its highest value was only 11.9 points. Meanwhile, the lowest value of IC publications was 2.5 points and the highest 17.2 points. The study showed that international collaboration between authors had a significant positive effect on the RGRI value. The median value of nonIC publications was 5.10, while the median of distinctive IC publications was 8.60 (non-IC mean 5.144; IC mean 9.073; t-value -4.909; df $67 ; p=0.000006$; non-OA $n=39$, OA $n=30$ ).

It was interesting to see if an RGRI value is be affected by other indicators of the analysed publications. Do publications that provide descriptions of new taxa (Table 4, Fig. 10) have higher RGRI values than publications that do not describe such taxa? We attempted to determine whether publications that provide diagnostic tools (as shown in Fig. 14) become more valuable from the RGRI perspective than publications that do not provide diagnostics. Does the fact that a publication examines plant-insect interactions, including new host plants and pests of cultivated plants, boost its RGRI value? It was also interesting to determine whether the RGRI value could be influenced by the wording of the publication title. Among the analysed publications, most had titles that we considered traditional, for example, 'Tischeriidae', 'The American species of the genus Glaucolepis
Braun', 'A provisional checklist of Nepticulidae of the Crimea. However, some publications had non-traditional titles, which, being fully aware of the subjectivity of the criterion, we considered intriguing or catchy. For example, 'The mystery of the tiny Urticaceae-feeders: documentation of the first leaf-mining Nepticulidae species from equatorial America,' 'Exceptional diversity of Tischeriidae from a single tropical forest site in Belize, Central America', 'Exoticlooking Neotropical Tischeriidae (Lepidoptera) and their host plants', 'A Gondwanan concept of Simplimorpha Scoble'.

Although the analysis data showed an increase in RGRI values in all analysed cases (Figs. 10, 11), significant and statistically significant changes in RGRI values were found within groups of publications with the subject related to plant-insect interactions and had intriguing (rather than traditional) titles.

It is understandable that the RGRI value is not a constant but a gradually increasing and accumulating indicator. Although among the analysed publications higher-rated (IF) papers were in a slightly lower starting position, the RGRI of both rated and non-rated publications (i.e., non-IF) rose almost equally, i.e., RGRI values roughly doubled over the four years of the survey. The change in the RGRI value (i.e., the rates of change over the years) was unrelated or little related to the papers being published in IF or non-IF journals (Figs. 12, 13).

Table 4. Selected examples of publications and the number of published new taxa

\begin{tabular}{c|c|cc}
\hline Short title of publication & Reference & $\begin{array}{c}\text { New } \\
\text { taxa }\end{array}$ & $\begin{array}{c}\text { RGRI } \\
\text { value }\end{array}$ \\
\hline New and little known Nepticulidae from the Asian continent & Stonis et al. 2020e & $\mathbf{1 1}$ & 0.6 \\
\hline Diagnostics and catalog of Opostegidae of the Americas & Stonis et al. 2020c & 5 & 5.9 \\
\hline Extraordinary sexual dimorphism of Stigmella pruinosa & Stonis et al. 2019g & - & 3.4 \\
\hline Ulmaceae-feedino Tischeriidae from China & Xu et al. 2018 & 1 & $\mathbf{1 0 . 7}$ \\
\hline Feeding strategies of Nepticulidae in Central \& South & Remeikis et al. 2016 & - & 7.3 \\
\hline Nepticulidae from record high altitudes & Stonis et al. 2016d & $\mathbf{2 2}$ & $\mathbf{1 1 . 0}$ \\
\hline A revision of the New World Opostegidae & Davis \& Stonis 2007 & $\mathbf{7 1}$ & $\mathbf{1 1 . 1}$ \\
\hline
\end{tabular}




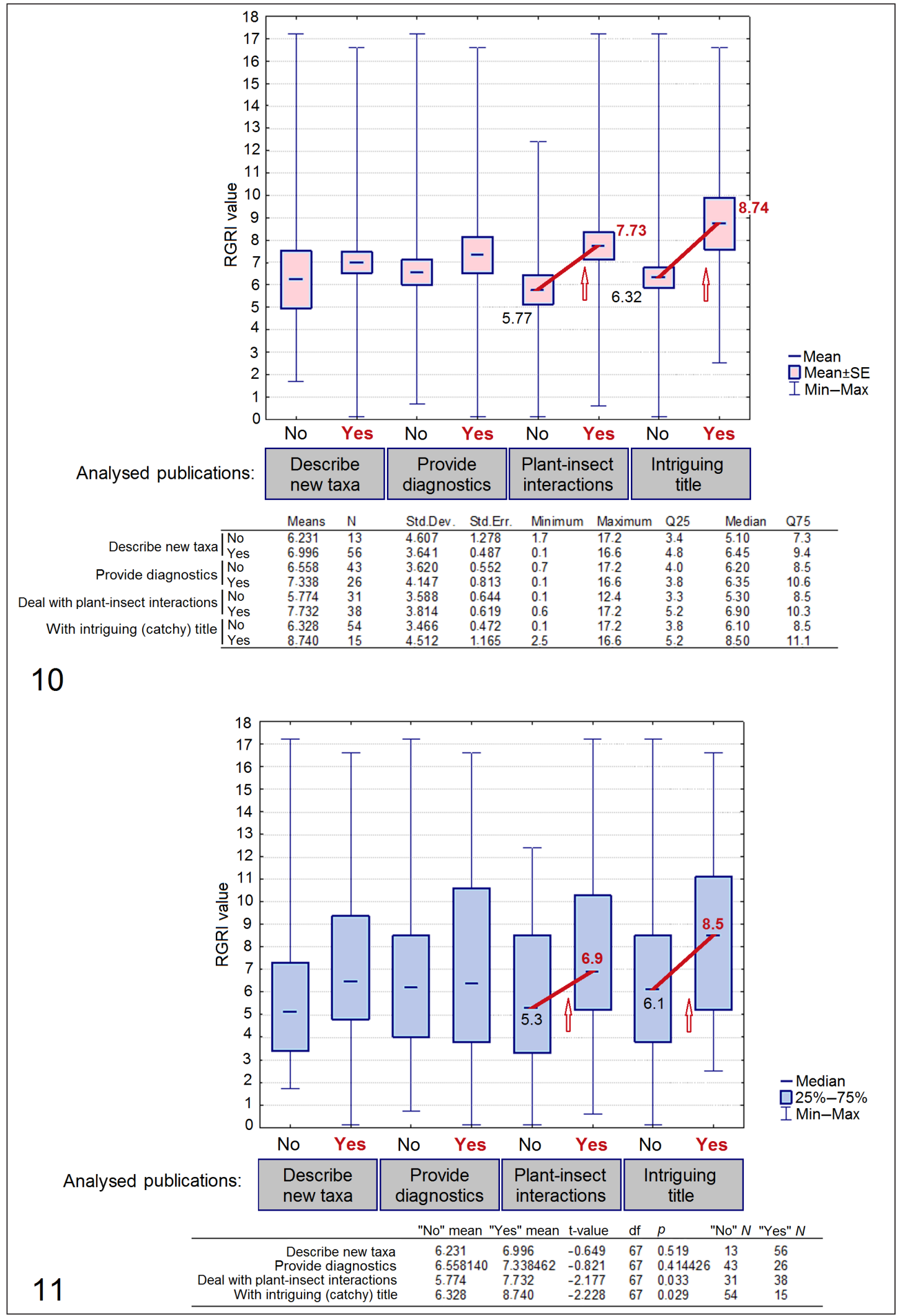

Figs. 10, 11. RGRI values compared with different characteristics of analysed publications. 10 - RGRI mean; 11 - RGRI median 


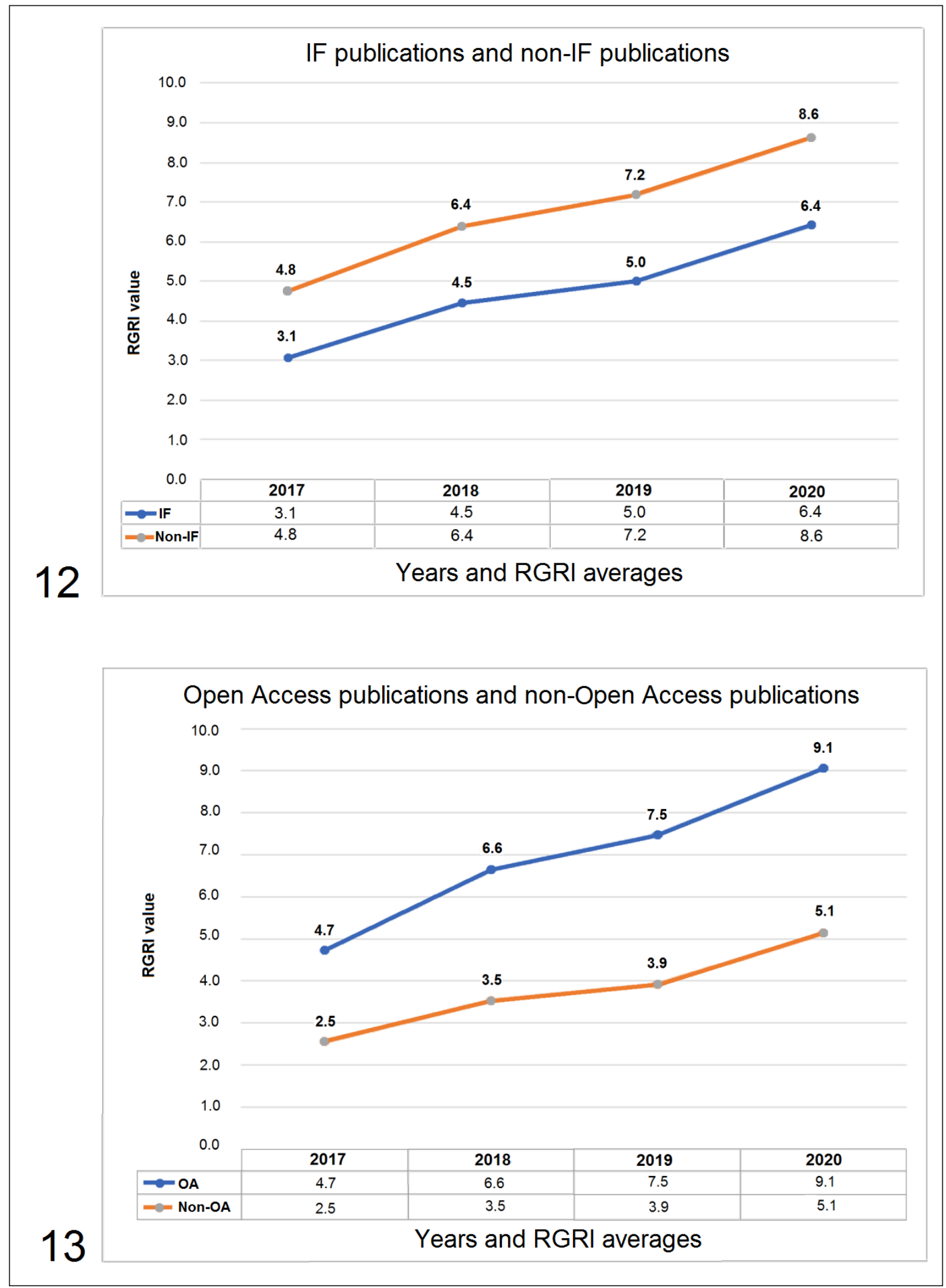

Figs. 12, 13. Growth rates of RGRI average over time. 12 - IF publications compared with non-IF publications; 13 - Open Access (OA) publications compared with non-OA publications 


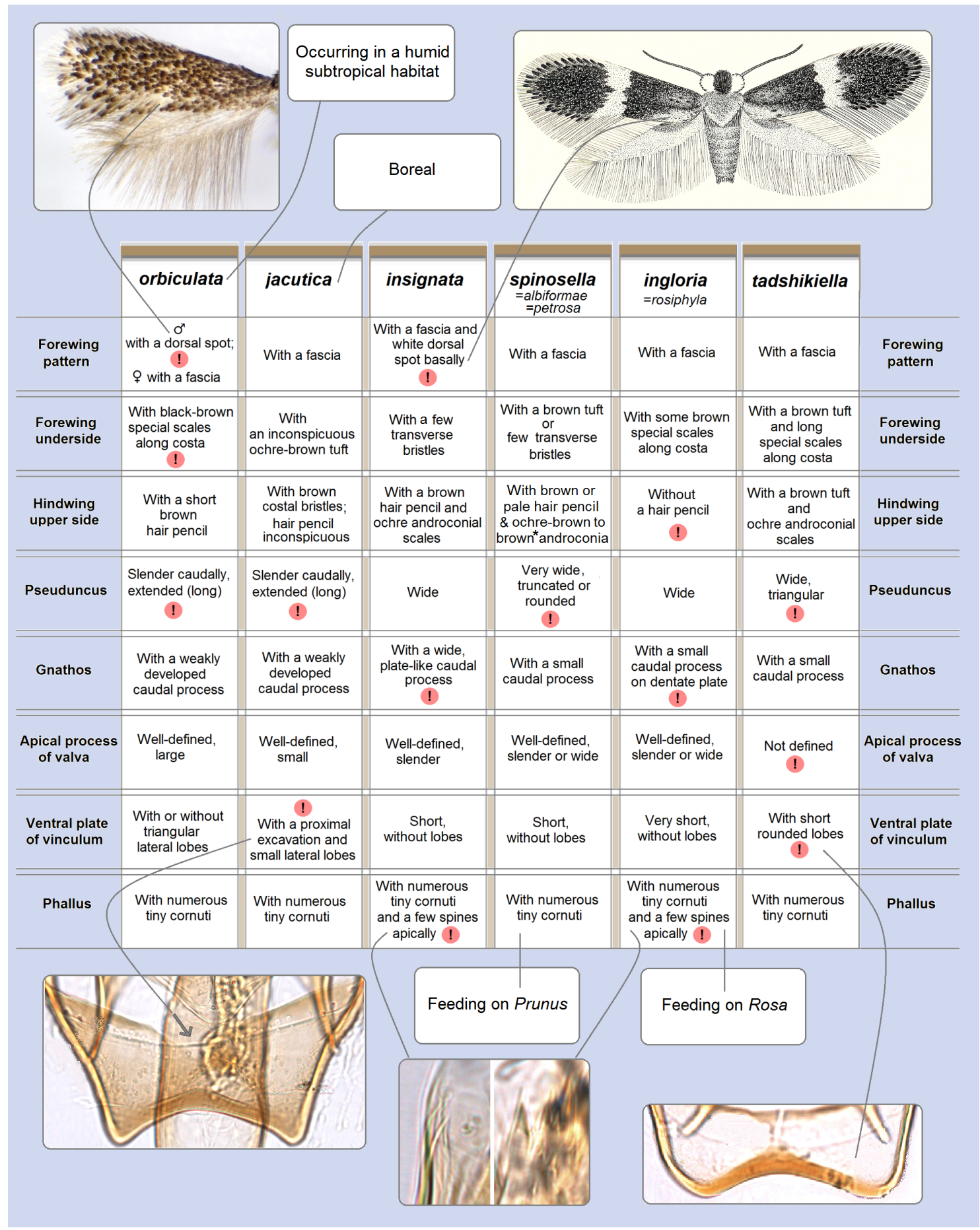

Fig. 14. An example of a pictorial diagnostic tool provided in a taxonomic publication (after Stonis et al., 2020e)

\section{CONCLUSIONS}

1. High RGRI scores for publications are not necessarily influenced (and often not influenced) by IF or high quartiles (Q), but open access to pub- lications certainly provides the strongest premises for the rise of the RGRI score, i.e., readability and citation of publications.

2. In addition to open access, the RGRI value is affected by various other characteristics 
of publications, including such factors as exceptional international cooperation, ecological aspects (as in the case of the analysed publications, plant-insect interactions), and an intriguing title of the publication.

3. RGRI values change over time, but despite their different starting positions, their growth rates do not depend on whether the publication is published in an impact factor (IF) or non-IF journal; RGRI growth rates are slightly faster for the publication that have open access compared to those that do not have it.

Note. In these times of commercialised and formalised science, professional researchers are indirectly yet systematically encouraged to abandon the preparation and publishing of papers in non-IF journals or in journals without high quartiles $(\mathrm{Q})$. However, we believe that this does not contribute to the most important goal, which is faster inventorying of biodiversity, and probably has the opposite effect.

\section{ACKNOWLEDGEMENTS}

We thank Dr Arūnas Diškus (Nature Research Centre, Lithuania) for his generous help in compiling the list of references.

This research was partially funded by a grant (S-MIP-19-30, 'DiagnoStics') from the Research Council of Lithuania.

The study by S. V. Baryshnikova was done within the State research project AAAAA19-119020690101-6.

O. V. Bidzilya carried out his part of the work on this article within the State Budget Programme 'Support for the Development of Priority Areas of Scientific Research', Ukraine (Code: 6541230).

Received 20 March 2021

Accepted 9 April 2021

\section{References}

1. Aagaard K, Berggren K, Hebert PDN, Sones J, McClenaghan B, Ekrem T. Investigating suburban micromoth diversity using DNA bar- coding of malaise trap samples. Urban Ecosyst. 2017; 20: 353-61. https://doi.org/10.1007/ s11252-016-0597-2

2. Aksnes DW, Langfeldt L, Wouters P. Citations, Citation Indicators, and Research Quality: An Overview of Basic Concepts and Theories. SAGE Open. 2019; 9(1): 1-17. https://doi. org/10.1177\%2F2158244019829575

3. Barreto ML, Aragão E, de Sousa LEPF, Santana TM, Barata RB. Differences between hindex measures from different bibliographic sources and search engines. Revista de Saúde Pública. 2013; 47(2): 231-8. https://doi. org/10.1590/S0034-89102013000100008

4. Bellard C, Bertelsmeier C, Leadley P, Thuiller W, Courchamp F. Impacts of climate change on the future of biodiversity. Ecol Lett. 2012; 15(4): 365-77. https://dx.doi. org/10.1111\%2Fj.1461-0248.2011.01736.x

5. Chawla DS. What's wrong with the journal impact factor in 5 graphs. Nature Index. 2018; Available from: https://www.natureindex. com/news-blog/whats-wrong-with-the-jif-infive graphs (accessed 12 March 2021)

6. Cutko A. Biodiversity Inventory of Natural Lands: A How-To Manual for Foresters and Biologists. NatureServe, Arlington, Virginia. 2009; 32 p. http://www.natureserve.org/biodiversityscience/publications/biodiversity-inventorynatural-lands-how-manual-foresters-and

7. Davis DR, Stonis JR. A revision of the New World plant-mining moths of the family Opostegidae (Lepidoptera: Nepticuloidae). Smithson Contrib Zool. 2007; 625, i-v + 212. https://doi.org/10.5479/si.00810282.625

8. De Prins J, De Prins W. Global taxonomic database of Gracillariida. 2012-2020; 2007e. Royal Museum for Central Africa \& Belgian Biodiversity Platform. Available from: http://www. gracillariidae.net (accessed 18 March 2021)

9. De Prins J, Heughebaert A. Afromoths, online database of Afrotropical moth species (Lepidoptera). Version 1.7. Belgian Biodiversity Platform. Available from: https://doi.org/10.15468/ s1kwuw (accessed 12 March 2021) 
10. Diškus A, Stonis JR. Astrotischeria neotropicana sp. nov. - a leaf-miner on Sida, Malvaceae, currently with the broadest distribution range in the Neotropics (Lepidoptera, Tischeriidae). Zootaxa. 2015; 4039(3): 456-66. https://doi. org/10.11646/zootaxa.4039.3.5

11. Falagas ME, Kouranos VD, Arencibia-Jorge R, Karageorgopoulos DE. Comparison of SCImago journal rank indicator with journal impact factor. FASEB Journal. 2008; 22(8): 2623-8. https://doi.org/10.1096/fj.08-107938

12. Froese R. Species 2000 additional common names for the Catalogue of Life (version Jan 2006). In: Roskov Y, Ower G, Orrell T, Nicolson D, Bailly N, Kirk PM, Bourgoin T, DeWalt RE, Decock W, van Nieukerken EJ, Zarucchi J, Penev L, editors. Species 2000 \& ITIS Catalogue of Life: 2019 Annual Checklist. Available from: http://www.sp2000.org/ (accessed 16 March 2021)

13. Girardello M, Chapman A, Dennis R, Kaila L, Borges PAV, Santangeli A. Gaps in butterfly inventory data: A global analysis. Biol Conserv. 2019; 236: 289-95. https://doi.org/10.1016/j. biocon.2019.05.053

14. Grummo DG, Zeliankevich NA, Tsvirko RV. Inventory and evaluation of the modern condition of the biological diversity of the National Park 'Belovezhskaya Pushcha' using remote and geoinformational methods. Sovremennye napravleniya razvitiya fizicheskoi geografii: nauchnye i obrazovatel'nye aspekty $\mathrm{v}$ tselyakh ustoichivogo razvitiya. BGU, Minsk; 2019. p. 353-6. http://elib.bsu.by/handle/123456789/234935

15. Hallmann CA, Sorg M, Jongejans E, Siepel H, Hofland N, Schwan H, Stenmans W, Müller A, Sumser H, Hörren T, Goulson D, de Kroon H. More than 75 percent decline over 27 years in total flying insect biomass in protected areas. PLoS ONE. 2017; 12(10): e0185809. https:// doi.org/10.1371/journal.pone.0185809

16. Hawksworth DL. Biodiversity and conservation of insects and other invertebrates. Biodivers Conserv. 2011; 20: 2863-6. https://doi. org/10.1007/s10531-011-0178-X
17. Janzen DH, Hallwachs W, Blandin $P$, Burns JM, Cadiou JM, Chacon I, Dapkey T, Deans AR, Epstein ME, Espinoza B, Franclemont JG, Haber WA, Hajibabaei M, Hall JP, Hebert PD, Gauld ID, Harvey DJ, Hausmann A, Kitching IJ, Lafontaine D, Landry JF, Lemaire C, Miller JY, Miller JS, Miller L, Miller SE, Montero J, Munroe E, Green SR, Ratnasingham S, Rawlins JE, Robbins RK, Rodriguez JJ, Rougerie R, Sharkey MJ, Smith MA, Solis MA, Sullivan JB, Thiaucourt P, Wahl DB, Weller SJ, Whitfield JB, Willmott KR, Wood DM, Woodley NE, Wilson JJ. Integration of DNA barcoding into an ongoing inventory of complex tropical biodiversity. Mol Ecol Resour. 2009; 1: 1-26. https://doi.org/10.1111/ j.1755-0998.2009.02628.x

18. Kirichenko N, Augustin S, Kenis M. Invasive leafminers on woody plants: a global review of pathways, impact, and management. JPest Sci. 2019; 92, 93-106. https://doi.org/10.1007/ s10340-018-1009-6

19. Kitching I. Sphingidae Taxonomic Inventory. Available from: http://sphingidae.myspecies. info (accessed 12 March 2021)

20. Klasiński A, Stonis JR, Remeikis A. Diagnostics based on the juxta morphology reveals a new species of Tischeria Zeller (Lepidoptera, Tischeriidae) from the Caucasus. Biologija. 2020; 66(1): 10-20. https://doi.org/10.6001/ biologija.v66i1.4186

21. La Salle J, Wheeler Q, Jackway P, Winterton S, Hobern D, Lovell D. Accelerating taxonomic discovery through automated character extraction. Zootaxa. 2009; 2217(1): 43-55. https:// doi.org/10.11646/zootaxa.2217.1.3

22. Lees DC, Stonis JR. The first record of Tischeriidae (Insecta: Lepidoptera) from Madagascar, with description of Coptotriche alavelona sp. n. and an updated distributional checklist of Afrotropical Tischeriidae. Zootaxa. 2007; 1645(1): 35-45. https://doi.org/10.11646/ zootaxa.1645.1.3

23. Leather S. 'Ecological Armageddon' - more evidence for the drastic decline in insect 
numbers. Ann Appl Biol. 2018; 172(1): 1-3. https://doi.org/10.1111/aab.12410

24. Lopez-Vaamonde C, Sire L, Rasmussen B, Rougerie R, Wieser C, Allaoui AA, Minet J, deWaard JR, Decaëns T, Lees DC. DNA barcodes reveal deeply neglected diversity and numerous invasions of micromoths in Madagascar. Genome. 2019; 62(3): 108-21. https:// doi.org/10.1139/gen-2018-0065

25. Mckinney ML. Urbanization, Biodiversity, and Conservation. BioScience. 2002; 52(10): 883-90. https://doi.org/10.1641/0006-3568 (2002)052 [0883:UBAC]2.0.CO;2

26. Miller SE. 22 - DNA barcoding in floral and faunal research. In: Watson MF, Lyal $\mathrm{CHC}$, Pendry CA, editors. Descriptive Taxonomy: the Foundation of Biodiversity Research. Cambridge University Press, Cambridge. 2015; p. 296-311. https://doi.org/10.1017/ CBO9781139028004.028

27. Miller SE, Hausmann A, Hallwachs W, Janzen DH. Advancing taxonomy and bioinventories with DNA barcodes. Philos Trans R SocLond B Biol Sci. 2016;371(1702): 20150339. https://dx.doi.org/10.1098\%2Frstb.2015.0339

28. Morton SR, Hill R. What is biodiversity and why it is important? In: Morton SR, Sheppard AW, Lonsdale WM, editors. Biodiversity, Science and Solutions for Australia, CSIRO Publishing, Collingwood, Melbourne. 2014; p. 1-12.

29. Navickaite A, Diškus A, Stonis JR. What is new and most interesting about the Nepticulidae of the Crimea and Lithuania. In: Stonis JR, Hill SR, Diškus A, Auškalnis T, editors. Selected abstracts and papers of the First Baltic International Conference on Field Entomology and Faunistics. Edukologija Publishers, Vilnius. 2014a; p. 96-117.

30. Navickaitė A, Diškus A, Stonis JR. An updated checklist of Nepticulidae (Lepidoptera) of the Crimea, Sub-Mediterranean SE Europe. Zootaxa. 2014b; 3847(2): 151-202. https://doi. org/10.11646/zootaxa.3847.2.1

31. Navickaitė A, Diškus A, Stonis JR, Dobrynina V. Taxonomic catalogue of the world Nep- ticuloidea and Tischerioidea (Lepidoptera) described by members of the Biosystematics Research Group (Lithuania) up to 2009. Acta Zool Litu. 2011; 21(2): 113-32. https://doi. org/10.2478/v10043-011-0014-2

32. Pereira H, Belnap J, Brummitt N, Collen N, Ding $\mathrm{H}$, Gonzales-Espinosa $\mathrm{M}$, Gregory R, Honrado J, Jongman RHG, Julliard R, McRae L, Proença V, Rodrigues P, Opige M, Rodríguez J, Schmeller DS, van Swaay C, Vieira C. Global Biodiversity Monitoring. Front Ecol Environ. 2010; 8(9): 459-60. https://doi. org/10.1890/10.WB.23

33. Pitkin B, Ellis W, Plant C, Edmunds R. The leaf and stem mines of British flies and other insects. (Coleoptera, Diptera, Hymenoptera and Lepidoptera). 2019. Available from: http://www.ukflymines.co.uk (accessed 12 March 2021)

34. Puplesis R. Biodiversity: an introduction to global animal and plant diversity. Kaunas: Lututè Publishers; 2002. 154 p. Lithuanian.

35. Puplesis R. The Nepticulidae of Eastern Europe and Asia: western, central and eastern parts. Backhuys Publishers, Leiden. 1994. p. 291, 840 figs.

36. Puplesis R, Diškus A. The Nepticuloidea \& Tischerioidea (Lepidoptera) - a global review, with strategic regional revisions. Kaunas: Lutute Publishers; 2003. 512 p.

37. Remeikis A, Diškus A, Stonis JR. Preliminary trophic analysis of leaf-mining Nepticulidae: pronounced feeding strategies in Middle and South America? Biologija. 2016; 62(4): 207-214. https://doi.org/10.6001/biologija.v62i4.3411

38. Remeikis A, Stonis JR. First discovery of Quercus-feeding Nepticulidae (Lepidoptera) in South America, with description of new species and designation of the S. nigriverticella complex in the S. saginella group. Zootaxa. 2015; 4057(3): 409-429. http://dx.doi.org/10.11646/ zootaxa.4057.3.7

39. Remeikis A, Stonis JR, Diškus A, Davis DR. Contribution to the Opostegidae fauna of Central America, with an updated checklist and description of new species from Costa 
Rica and Mexico (Insecta: Lepidoptera). Acta Zool Litu. 2009; 19(4): 278-86. https://doi. org/10.2478/v10043-009-0034-3

40. Remeikis A, Stonis JR, Diškus A, Davis DR. The first photographic documentation and new data on Enteucha guajavae (Lepidoptera, Nepticulidae), a pest of guava from equatorial America. In: Stonis JR, Hill SR, Diškus A, Auškalnis T, editors. Selected abstracts and papers of the First Baltic International Conference on Field Entomology and Faunistics. Vilnius: Edukologija Publishers; 2014. p. 65-74.

41. Robinson GS. Tineidae NHM: Global Taxonomic Database of Tineidae (Lepidoptera) in the Catalogue of Life. 2019. Available from: https://doi.org/10.15468/4vwckx (accessed 15 March 2021)

42. Rocienè A, Stonis JR. Nepticulidae (Lepidoptera) of East Asia (2). Study of a collection sample deposited at the Russian Academy of Sciences, with descriptions of new species and a checklist. Zootaxa. 2013; 3652(1): 75-116. http://dx.doi.org/10.11646/zootaxa.3652.1.

43. Rocienè A, Stonis JR. Revised fauna of the Nepticulidae (Lepidoptera) of continental East Asia: lots of effort to elucidate the littleknown diversity of pygmy moths. In: Stonis JR, Hill SR, Diškus A, Auškalnis T, editors. Selected abstracts and papers of the First Baltic International Conference on Field Entomology and Faunistics. Vilnius: Edukologija Publishers: 2014. p. 51-62.

44. Sánchez-Bayo F, Wyckhuys KAG. Worldwide decline of the entomofauna: A review of its drivers. Biol Conserv. 2019; 232: 8-27. https:// doi.org/10.1016/j.biocon.2019.01.020

45. Schmeller D, Böhm M, Arvanitidis C, Barber-Meyer S, Brummitt N, Chandle $M$, Chatzinikolaou E, Costello M, Ding $\mathrm{H}$, Garcia Moreno J, Gill M, Haase P, Jones M, Juillard R, Magnusson W, Martin C, McGeoch M, Mihoub JB, Pettorelli N, Belnap J. Building capacity in biodiversity monitoring at the global scale. Biodivers Conserv. 2017; 26: 2765-90. https://doi.org/10.1007/s10531017-1388-7
46. Sharkey MJ, Janzen DH, Hallwachs W, Chapman EG, Smith MA, Dapkey T, Brown A, Ratnasingham S, Naik S, Manjunath R, Perez K, Milton M, Hebert P, Shaw SR, Kittel RN, Solis MA, Metz MA, Goldstein PZ, Brown JW, Quicke DLJ, van Achterberg C, Brown BV, Burns JM. Minimalist revision and description of 403 new species in 11 subfamilies of Costa Rican braconid parasitoid wasps, including host records for 219 species. ZooKeys. 2021; 1013: 1-665. https://doi.org/10.3897/ zookeys. 1013.55600

47. Sinev SYu, editor. Catalogue of the Lepidoptera of Russia. KMK Scientific Press, St. Petersburg, Moscow. 2008; p. 424. Russian.

48. Sinev SYu, edidor. Catalogue of the Lepidoptera of Russia. Edition 2. Zoological Institute RAS, St. Petersburg. 2019; p. 448. Russian.

49. Stephenson PJ, Stengel C. An inventory of biodiversity data sources for conservation monitoring. PLoS ONE. 2020; 15(12): e0242923. https://doi.org/10.1371/journal. pone.0242923

50. Stonis JR. Preface. In: Stonis JR, Hill SR, Diškus A, Auškalnis T, editors. Selected abstracts and papers of the First Baltic International Conference on Field Entomology and Faunistics. Edukologija Publishers, Vilnius. 2014; p. 65-74.

51. Stonis JR, Diškus A. Description of Tischeria gouaniae sp. $\mathrm{n}$. from the tropical forest of $\mathrm{Be}$ lize - an exotic new addition to the American fauna of Tischeria (Insecta: Lepidoptera: Tischeriidae). Zoolog Sci. 2007; 24(12): 128691. https://doi.org/10.2108/zsj.24.1286

52. Stonis JR, Diškus A. Checklist of American Coptotriche (Insecta: Lepidoptera: Tischeriidae) with descriptions of two new species from the tropical forest of Belize (Central America). Zoolog Sci. 2008; 25(1): 99-106. https://doi. org/10.2108/zsj.25.99

53. Stonis JR, Diškus A. Acalyptris amazonensis sp. nov.: documentation of another leafmining species supplementing the unique but disputable A. latipennata group (Lepidoptera: 
Nepticulidae). Biologija. 2018; 64(3): 191-202. https://doi.org/10.6001/biologija.v64i3.3824

54. Stonis JR, Diškus A, Carvalho Filho F, Lewis OT. American Asteraceae-feeding Astrotischeria species with a highly modified, threelobed valva in the male genitalia (Lepidoptera, Tischeriidae). Zootaxa. 2018a; 4469(1): 1-69. https://doi.org/10.11646/zootaxa.4469.1.1

55. Stonis JR, Diškus A, Fernández-Alonso JL, Remeikis A, Solis MA. New leaf-mining Nepticulidae (Lepidoptera): potential pests of aromatic Lamiaceae plants from equatorial Andes. Zootaxa. 2021a; 4926(3): 363-83. DOI: https://doi.org/10.11646/zootaxa.4926.3.3

56. Stonis JR, Diškus A, Katinas L, Solis MA. Asteraceae: host to the greatest diversity of leafmining Nepticulidae (Lepidoptera) in South America? Proc Entomol Soc Wash. 2018b; 120(4): 856-902. https://doi.org/10.4289/00138797.120.4.856

57. Stonis JR, Diškus A, Mey W. Tischeriidae (Lepidoptera: Tischerioidea). In: Mey W, Krüger M, editors. The Lepidoptera fauna of a crater valley in the Great Escarpment of South Africa: The Asante Sana Project. Esperiana Memoir, 8. Esperiana-Verlag, Deutschland. 2019a; p. $85-98$.

58. Stonis JR, Diškus A, Paulavičiūte B, Monro AK. Urticaceae-feeders from the family Tischeriidae: descriptions of two new species and new genus Paratischeria gen. nov. Biologija. 2017a; 63(1): 1-22. https://doi.org/10.6001/ biologija.v63i1.3470

59. Stonis JR, Diškus A, Remeikis A. The first description of the leaf-mining Nepticulidae (Lepidoptera) feeding on the South American plant genus Liabum, Asteraceae. Zootaxa. 2015a; 4040(5): 576-82. https://doi. org/10.11646/zootaxa.4040.5.6

60. Stonis JR, Diškus A, Remeikis A, Cumbicus Torres N. First description of leaf-mining Nepticulidae and Tischeriidae (Insecta, Lepidoptera) feeding on the Chilean endemic plant genus Podanthus Lag. (Asteraceae).
Zootaxa. 2016a; 4061(2): 119-30. http://doi. org/10.11646/zootaxa.4061.2.2

61. Stonis JR, Diškus A, Remeikis A, Cumbicus Torres N. Rosaceae-feeding Nepticulidae (Lepidoptera) of South America: some taxonomic and trophic diversity revealed. Biologija. 2016b; 62(4): 215-32. https://doi. org/10.6001/biologija.v62i4.3412

62. Stonis JR, Diškus A, Remeikis A, Davis DR, Solis MA, Cumbicus Torres N. The first record of Baccharis L. (Asteraceae) as a host-plant genus for Nepticulidae (Lepidoptera), with description of new Stigmella species from South America. Zootaxa. 2016c; 4136(1): 101-28. http://doi.org/10.11646/zootaxa.4136.1.4

63. Stonis JR, Diškus A, Remeikis A, Gerulaitis V, Karsholt O. Leaf-mining Nepticulidae (Lepidoptera) from record high altitudes: documenting an entire new fauna in the Andean páramo and puna. Monograph. Zootaxa. 2016d; 4181(1): 1-94. http://doi.org/10.11646/ zootaxa.4181.1.1

64. Stonis JR, Diškus A, Remeikis A, Karsholt O. Do leaf-mining Nepticulidae occur in the natural but so threatened Andean Polylepis forests? Biologija. 2016e; 62(2): 83-97. http:// dx.doi.org/10.6001/biologija.v62i2.3334

65. Stonis JR, Diškus A, Remeikis A, Karsholt O, Cumbicus Torres N. Illustrated review of the leaf-mining Nepticulidae (Lepidoptera) of the central Andes (Peru and Bolivia). Zootaxa. 2017b; 4257(1): 1-70. https://doi. org/10.11646/zootaxa.4257.1.1

66. Stonis JR, Diškus A, Remeikis A, Katinas L, Cumbicus Torres N, Schuster J, PuplesyteChambers J. Diagnostics of new species of Neotropical Tischeriidae (Lepidoptera), with the first record of Coptotriche Walshingham from South America. Zootaxa. 2019b; 4691(1): 1-32. https://doi.org/10.11646/zootaxa.4691.1.1

67. Stonis JR, Diškus A, Remeikis A, Lewis OT. Exceptional diversity of Tischeriidae (Lepidoptera) from a single tropical forest site 
in Belize, Central America. Eur J Taxon. 2020a; 723: 33-76. https://doi.org/10.5852/ ejt.2020.723.1143

68. Stonis JR, Diškus A, Remeikis A, Monro A. The mystery of the tiny Urticaceae-feeders: documentation of the first leaf-mining Nepticulidae (Lepidoptera) species from equatorial America associated with Phenax, Boehmeria and Pilea. Biologija. 2017c; 63(2): 105-25. https://doi.org/10.6001/biologija.v63i2.3523

69. Stonis JR, Diškus A, Remeikis A, Navickaitė A, Rocienè A. Description of new species of oak leaf-miners (Lepidoptera: Nepticulidae), with notes on the species groups of Stigmella Schrank associated with Quercus as a hostplant. Zootaxa. 2013a; 3737(3): 201-22. https://doi.org/10.11646/zootaxa.3737.3.1

70. Stonis JR, Diškus A, Remeikis A, Nishida K. Discovery of a new species of Ozadelpha van Nieukerken sheds more light on the diagnostics of this controversial genus of Nepticulidae (Lepidoptera). Biologija. 2019c; 65(4): 223-35. https://doi.org/10.6001/biologija. v65i4.4116

71. Stonis JR, Diškus A, Remeikis A, Noreika R, Schuster J. Four new leaf-mining Acalyptris species from Guatemala and Belize, with new data on bionomics of Stigmella pruinosa (Lepidoptera: Nepticulidae). Zootaxa. 2013b; 3737(2): 101-17. https://doi.org/10.11646/ zootaxa.3737.2.1

72. Stonis JR, Diškus A, Remeikis A, Schuster J. First discovery of Quercus feeding Nepticulidae (Lepidoptera) in Central America. Zootaxa. 2013c; 3737(1): 1-23. https://doi. org/10.11646/zootaxa.3737.1.1

73. Stonis JR, Diškus A, Remeikis A, Solis MA. The American Brachinepticula gen. nov. and Manoneura Davis (Nepticulidae): a new generic concept based on a reinforced cathrema in the phallus. Biologija. 2018c; 64(2): 99-128. https://doi.org/10.6001/biologija.v64i2.3735

74. Stonis JR, Diškus A, Remeikis A, Solis MA. A Gondwanan concept of Simplimorpha Scoble (sensu lato): a step toward clarity in the generic diagnostics of global Nepticulidae (Lepidoptera). Zootaxa. 2018d; 4521(2): 15182. https://doi.org/10.11646/zootaxa.4521.2.1

75. Stonis JR, Diškus A, Remeikis A, Solis MA, Katinas L. Exotic-looking Neotropical Tischeriidae (Lepidoptera) and their host plants. ZooKeys. 2020b; 970: 117-58. https://doi. org/10.3897/zookeys.970.54801

76. Stonis JR, Diškus A, Remeikis A, Vargas AS, Solis MA. Diagnostics and updated catalogue of Acalyptris Meyrick, the second largest genus of Nepticulidae (Lepidoptera) in the Americas. Zootaxa. 2020c; 4748(2): 201-47. https:// doi.org/10.11646/zootaxa.4748.2.1

77. Stonis JR, Diškus A, Rocienè A, Sruoga V, Davis DR. New and little known Coptotriche and Tischeria species (Lepidoptera: Tischeriidae) from Primorskiy Kray, Russian Far East. Zootaxa. 2014a; 3884(2): 141-55. https://doi. org/10.11646/zootaxa.3884.2.3

78. Stonis JR, Diškus A, Solis MA. Two new Fabaceae-feeding Nepticulidae (Lepidoptera) from the Western Hemisphere, including a potential pest of the economically important Centrolobium Mart. ex Benth. Proc Entomol Soc Wash. 2018e; 120(4): 842-55. https://doi. org/10.4289/0013-8797.120.4.842

79. Stonis JR, Diškus A, Sruoga V. Redescription of Coptotriche pulverea (Walsingham) - an unusual species of the American Tischeriidae fauna (Insecta: Lepidoptera). Acta Zool Litu. 2008; 18(3): 169-73. https://doi.org/10.2478/ v10043-008-0023-y

80. Stonis JR, Diškus A, Vargas S. Discovery of leaf-mining Tischeriidae (Lepidoptera) in Colombia and their distribution in the Neotropics. Zootaxa. 2019d; 4638(2): 219-36. https:// doi.org/10.11646/zootaxa.4638.2.3

81. Stonis JR, Navickaitè A, Diškus A. A puzzle regarding the Siberian Ectoedemia jacutica (Lepidoptera: Nepticulidae): re-examination and the first photographic documentation of the type series. Biologija. 2015b; 61(3-4): 116-22. https://doi.org/10.6001/biologija.v61i34.3203 
82. Stonis JR, Remeikis A. Acalyptris platani (Müller-Rutz) in the Crimea, Ukraine - The Easternmost record of the Sub-mediterranean species in Europe (Insecta: Lepidoptera: Nepticulidae). Acta Zool Litu. 2011; 21(2): 89-95. https://doi.org/10.2478/v10043-011-0011-5

83. Stonis JR, Remeikis A. The first records on the genus Acalyptris from the Caribbean (Lepidoptera: Nepticulidae). Zootaxa. 2015; 4057(1): 79-90. https://doi.org/10.11646/ zootaxa.4057.1.4

84. Stonis JR, Remeikis A. Southern Andean Stigmella sinuosa complex (Lepidoptera, Nepticulidae): unraveling problematic taxonomy with a pictorial key of adults? Zootaxa. 2016; 4136(2): 30922. http://doi.org/10.11646/zootaxa.4136.2.3

85. Stonis JR, Remeikis A. Anacardiaceae-feeding Nepticulidae in the Neotropics: description of Stigmella lilliputica sp. nov. from Argentina, a pest on Chilean peppertree Schinus polygama. Biologija. 2017; 63(3): 230-37. https://doi. org/10.6001/biologija.v63i3.3577

86. Stonis JR, Remeikis A. Odd species of Nepticulidae (Lepidoptera) from the American rainforest and southern Andes. Zootaxa. 2018; 4392(3): 458-68. https://doi.org/10.11646/ zootaxa.4392.3.2

87. Stonis JR, Remeikis A, Davis DR. Ten new species from the Patagonian Andes (Argentina and Chile), mostly belonging to a newly designated Stigmella purpurimaculae group (Lepidoptera: Nepticulidae). Zootaxa. 2014b; 3887(3): 321-53. https://doi.org/10.11646/ zootaxa.3887.3.3

88. Stonis JR, Remeikis A, Diškus A, Baryshnikova S, Solis MA. What are the smallest moths (Lepidoptera) in the world? Zootaxa. 2021b; 4942(2): 269-89. https://doi.org/10.11646/ zootaxa.4942.2.8

89. Stonis JR, Remeikis A, Diškus A, Davis DR, Solis MA. American Tischeriidae (Lepidoptera) from the collection of the National Museum of Natural History, Washington D.C. Proc Entomol Soc Wash. 2020d; 122(2): 482-505. https://doi.org/10.4289/0013-8797.122.2.482
90. Stonis JR, Remeikis A, Diškus A, Forero D, Cumbicus Torres N. A report on Lamiaceaefeeding Nepticulidae (Lepidoptera) from South America. Zootaxa. 2017d; 4338(1): $128-$ 40. https://doi.org/10.11646/zootaxa.4338.1.6

91. Stonis JR, Remeikis A, Diškus A, Gerulaitis V. The Ando-Patagonian Stigmella magnispinella group (Lepidoptera, Nepticulidae) with description of new species from Ecuador, Peru and Argentina. Zootaxa. 2016f; 4200(4): 56179. http://doi.org/10.11646/zootaxa.4200.4.7

92. Stonis JR, Remeikis A, Diškus A, Megoran N. New species of leaf-mining Nepticulidae (Lepidoptera) from the Neotropical and AndoPatagonian regions, with new data on hostplants. Zootaxa. 2017e; 4272(1): 1-39. https:// doi.org/10.11646/zootaxa.4272.1.1

93. Stonis JR, Remeikis A, Diškus A, Navickaitè A. Documenting new and little known leafmining Nepticulidae from middle and southwestern areas of the Asian continent. Zootaxa. 2020e; 4881(3): 401-52. https://doi. org/10.11646/zootaxa.4881.3.1

94. Stonis JR, Remeikis A, Diškus A, Noreika R. New Nepticulidae species (Insecta, Lepidoptera) from the Yucatán Peninsula (SE Mexico). Zootaxa. 2013d; 3609(2): 223-30. https://doi. org/10.11646/zootaxa.3609.2.8

95. Stonis JR, Remeikis A, Diškus A, Orlovskytè S, Vargas SA, Solis MA. A new leafmining pest of guava: Hesperolyra guajavifoliae sp. nov., with comments on the diagnostics of the endemic Neotropical genus Hesperolyra van Nieukerken (Lepidoptera, Nepticulidae). ZooKeys. 2019e; 900: 87-110. https://doi.org/10.3897/ zookeys. 900.46332

96. Stonis JR, Remeikis A, Diškus A, Solis MA. The American species of the genus Glaucolepis Braun, 1917 (Neotrifurcula van Nieukerken, syn. nov.) (Lepidoptera: Nepticulidae). Zootaxa. 2017f; 4338(3): 489-506. https://doi. org/10.11646/zootaxa.4338.3.5

97. Stonis JR, Remeikis A, Diškus A, Vargas SA, Solis MA. Opostegidae (Lepidoptera) of the Americas: updated catalog, diagnostics, 
and new species descriptions. Proc Entomol Soc Wash. 2020f; 122(4): 929-72. https://doi. org/10.4289/0013-8797.122.4.929

98. Stonis JR, Remeikis A, Gerulaitis V, Forero D. An embarrassing situation requiring urgent action: Colombia, a country of extraordinary biodiversity, still counts only few species of Nepticuloidea (Insecta, Lepidoptera). Biologija. 2015c; 61(3/4): 123-29. https://doi. org/10.6001/biologija.v61i3-4.3204

99. Stonis JR, Remeikis A, Sruoga V. An annotated list of the Opostegidae of the Himalaya, with a description of Pseudopostega brevicaudata sp. nov. (Lepidoptera: Nepticuloidea). Zootaxa. 2013e; 3609(2): 182-94. https://doi. org/10.11646/zootaxa.3609.2.4

100. Stonis JR, Remeikis A, Vargas S. Colombian Nepticuloidea and Tischerioidea: a small step out of obscurity? Biologija. 2019f; 65(2): 48-55. https://doi.org/10.6001/biologija.v65i2.4023

101. Stonis JR, Remeikis A, Vargas S. Stigmella pruinosa (Lepidoptera: Nepticulidae), a species feeding on Guazuma and exhibiting extraordinary sexual dimorphism, now known to be occurring from Mexico to Colombia. Biologija. 2019g; 65(3): 151-64. https://doi. org/10.6001/biologija.v65i3.4084

102. Stonis JR, Rocienė A. Nepticulidae (Lepidoptera) of East Asia (1). Re-examination of the male genitalia of types deposited at the Russian Academy of Sciences. Zootaxa. 2013; 3652(1): 1-59. http://dx.doi.org/10.11646/zootaxa.3652.1.1

103. Stonis JR, Rociene A. Additions to the Nepticulidae (Lepidoptera) of East Asia, with descriptions of three new species from Primorskiy Kray. Zootaxa. 2014; 3846(2): 204-20. https://doi.org/10.11646/zootaxa.3846.2.2

104. Stonis JR, Solis MA. Dishkeya gen. nov., a New World endemic genus of leaf-mining Tischeriidae (Lepidoptera), transferred from Tischeria Zeller. Biologija. 2020; 66(3): 123-35. https:// doi.org/10.6001/biologija.v66i3.4307

105. Stonis JR, Sruoga V, Diškus A, Remeikis A, Auksoriūtė A, Žvironienè J. A review of insect groups with proposals on Lithuanian termi- nology. Part 1: Archaeognatha - Hemiptera, Heteroptera. Electronic Version in Color. Lithuanian University of Educational Sciences Publishers, Vilnius. 2016g; p. 320. Lithuanian.

106. Šimkevičiūtè A, Stonis JR, Diškus A. Taxonomic checklist of Nepticulidae of Mexico, with the description of three new species the from Pacific Coast (Insecta, Lepidoptera). Acta Zoologica Lituanica. 2009; 19(4): 268-77. https://doi.org/10.2478/v10043-009-0037-0

107. Vane-Wright RI. Systematics and global biodiversity strategy. Antenna. 1992; 16: 49-56.

108. Vane-Wright RI. Systematics and the Conservation of Biological Diversity. Ann Mo Bot Gard. 1996; 83(1): 47-57. https://doi. org/10.2307/2399967

109. Vermeulen S, Koziell I. Integrating global and local values: a review of biodiversity assessment. International Institute for Environment and Development, London. 2002; p. 104.

110. Xu J, Dai X, Liao C, Diškus A, Stonis JR. Discovery of Ulmaceae-feeding Tischeriidae (Lepidoptera, Tischerioidea), Tischeria ulmella sp. nov., and the first report of the Quercus-feeding T. naraensis Sato in China. Zootaxa. 2018; 4399(3): 361-70. https://doi.org/10.11646/ zootaxa.4399.3.6

111. Xu J, Dai X, Liu P, Bai H, Diškus A, Stonis JR. First report on Paratischeria from Asia (Lepidoptera: Tischeriidae). Zootaxa. 2017; 4350(2): 331-44. https://doi.org/10.11646/ zootaxa.4350.2.8

112. Zattara E, Aizen M. Worldwide occurrence records suggest a global decline in bee species richness. One Earth. 2021; 4(1): 114-23. https://doi.org/10.1016/j.oneear.2020.12.005

113. Zhang Z-Q. Accelerating biodiversity descriptions and transforming taxonomic publishing: The first decade of Zootaxa. Zootaxa. 2008; 2896(1): 1-7. https://doi.org/10.11646/ zootaxa.2896.1.1

114. Zhang Z-Q. Describing unexplored biodiversity: Zootaxa in the International Year of Biodiversity. Zootaxa. 2011; 2768(1): 1-4. https:// doi.org/10.11646/zootaxa.2768.1.1 
Viktorija Dobrynina, Svetlana Baryshnikova,

Eduardas Budrys, Jolanta Rimšaitė,

Oleksiy Bidzilya

\section{PUBLIKUOTI BIOLOGINĖS İVAIROVĖS IN- VENTORIZACIJOS PRODUKTAI: AR TIK CI- TAVIMO RODIKLIS (IF) BEI KVARTILĖS (Q) NULEMIA JŲ POPULIARUMĄ IR SVARBĄ?}

\section{Santrauka}

Žurnalo citavimo rodiklis (IF) arba aukštos kvartilès (Q1, Q2) nebūtinai nulemia aukštesnes „Research Gate Research Interest" (RGRI) rodiklio reikšmes, publikacijų populiarumą ir svarbą. Tačiau laisva publikacijų prieiga neabejotinai sudaro didžiausias prielaidas RGRI balo kilimui, t. y. publikacijų skaitomumui ir cituojamumui. Be atviros prieigos, RGRI rodiklio dydžiui turi įtakos ir ịvairios kitos straipsnių charakteristikos. Autorių duomenimis, didžiausią reikšmę gali turèti tokie veiksniai kaip tarptautinis bendradarbiavimas, ekologinių klausimų nagrinejimas (pvz., augalų ir vabzdžiu sąveika) bei pati straipsnio pavadinimo formuluotè. RGRI rodiklio reikšmès kinta laike, tačiau nepaisant skirtingų starto pozicijų, jų didejjimo tempas nepriklauso nuo to, ar publikacija yra paskelbta aukšto citavimo (IF) žurnale ar nereitinguotame mokslo leidinyje; šiek tiek spartesnis publikacijų RGRI rodiklio didèjimas pastebimas tarp tų publikacijų, kurios yra laisvos prieigos. Šiais komercializuoto ir formalizuoto mokslo laikais profesionalūs tyrejai netiesiogiai, tačiau sistemiškai yra skatinami nepublikuoti straipsnių nereitinguotuose žurnaluose arba žurnaluose, neturinčiuose aukštų kvartilių. Straipsnio autoriai mano, kad tai nè kiek neskatina svarbiausio tikslo siekimo - greitesnès biologinès įvairovès inventorizacijos, netgi tikriausiai daro priešingą poveikį.

Raktažodžiai: žurnalo reitingas, taksonų diagnostika, tarptautinis bendradarbiavimas, nauji taksonai, atvira prieiga, augalų ir vabzdžių sąveika, straipsnio pavadinimas 